\title{
The Principals' Leadership As Academic Supervisor In Elementary School
}

\author{
Mariyatul Fikriyah, Yatim Riyanto, Sulasminten \\ Universitas Negeri Surabaya \\ Surabaya, Indonesia \\ mariyatul.fikriyah94@gmail.com
}

\begin{abstract}
This study aims to determine the leadership of the principal as an academic supervisor, supporting factors and inhibiting the implementation of academic supervision. This research uses qualitative approach with case study type. The result is that the principal work with teachers and other stakeholders in achieving school goals, facilities and infrastructure from donors and governments, decisions are taken by deliberation and direct from the principal. The principal has a good relationship with the school and the surrounding community, the role of the supervisor starts from preparing the schedule, using the necessary techniques and then following up, the supporting factor is that teachers have an awareness of the importance of academic supervision and the obstacles consist of: teachers' difficulty in completing learning tools and business of schools' headmaster with departmental tasks. The supervision is done to improve teachers' ability to learn in school.
\end{abstract}

Keywords—principal leadership; academic supervision

\section{INTRODUCTION}

Every school must have its own vision, mission and goals. To achieve the objectives of the school it needs planning, implementation to evaluation of programs and activities. Every school continually strives to improve the school system, to achieve the expected school's goal together. In the planning to the evaluation, it needs a leader who is fully responsible for everything that happens in school. Leadership is held by the principal who is trusted to direct the citizens of schools to achieve schools' goals by dividing the task, so that the implementation of programs and activities can be jointly achieved.

According to Bass, leadership is the interaction between two or more members of the group involved in the arrangement and perception and expectations of the members [1]. Dubrin stated that leadership is the ability to inspire trust and support from members to achieve organizational goals [2]. According to Davis, leadership is the ability to persuade people to achieve organizational goals that requires the principal to have a good managerial strategy [3]

The principal as a leader has several duties and obligations, such as in leading the planning in achieving the goal, it is necessary for cooperation between principal and the teachers. Pettigrew describes a leader as someone who is requiring the assistance of its members in completing the task of the organization [4]. It agrees with [5] that the interaction between leaders and their subordinates (followers) contribute to determining the success of a team in a hierarchical organization.

In addition, the principal also has responsibilities regarding the completeness of facilities and infrastructure in schools. According Dubrin a leader has several abilities, one of them is the ability to adapt [2]. Gibbs, Knapper, and Piccinin argued that a leader must be able to adapt to the surrounding cultural system [6]. Luthra and Dahlya described that a leader is not able to become an effective leader unless he is an excellent communicator and must use his or her ability to let other to follow him or her [7].

The principal has several main tasks, one of which is as an academic supervisor. This supervisory activity can help teachers in carrying out learning with learners, providing solutions, helping teachers in choosing methods and learning techniques according to the material. Peretomode described supervision as a way to influence teachers to do their job well so as to create a conducive climate for effective learning [8].

At present time there is much research on academic supervision in some schools but using only one particular supervision technique. So it seems as if only one technique is good to be used in academic supervision. Indeed, academic supervision has a variety of techniques that can be used and can help the principal to know the ability of teachers as a whole. But this research did not specify a single technique studied, but rather investigating the academic supervision so widely. It is more than one supervision technique that was used that could help the principal as a leader to know the ability of other teacher.

According to Sudarman, a leader has an obligation to help developing the ability of its members by providing guidance, training and motivation in performing the task [9]. Purwanto argued that the principal has an obligation to uplift the spirit of the teachers, establish good relationships, and seek the teachers' welfare, it is the function of the principal as a supervisor [10].

The principal as a supervisor has the obligation to guide the teachers in learning with the learners. The principal must have the capability of knowing the learning tools and appropriate teaching methods of the learning material. Based on the above elaboration, the focus on this research is: (1) how is the principal's leadership in primary schools? (2) How is the role of principal as an academic supervisor in primary school? (3) How are the supporting factors in the implementation of 
academic supervision in primary schools? And (4) how are the hinder factors in the implementation of academic supervision in primary schools?

\section{METHOD}

This research is a qualitative research approach that relies on descriptive manner employing of words, or sentences, which are carefully and systematically compiled from data collecting to interpreting and reporting research results. The informants from this study were the principal, several teachers and students. Primary data were obtained from the information provided by the principal, several teachers and students, while secondary data were obtained from documents or archives related to the implementation of academic supervision in schools. Data collection methods used in-depth interviews, observation and documentation.

Data analysis used three techniques from Milles and Huberman that are data condensation, data display, verification and conclusion [11]. Data validity (credibility) was done by Prolonged Engagement, Persistent Observation, Triangulation, Peer Debriefing, Referential Adequacy Checks, and Member Checks. It also used the Dependability technique, Conformability and Transferability by a competent expert in their field.

\section{RESULTS AND DISCUSSION}

\section{A. Principal Leadership}

\section{1) Efforts in Achieving Goals}

The principal is the highest leader in the school who is responsible for the entire schools' activities. The principal's leadership is an effort to achieve the school's objective that begins with a joint meeting, and then proceed with the division of tasks until the evaluation process. This is in line with the opinion of Dubrin, stating that Leadership is the ability to inspire the trust and benefits the members and group members. In the division of tasks, it is carried out according to the ability of each member to carry out the task correctly [2]. This is in line with the opinion of Pettigrew, namely the ability carried out by members / subordinates that can be used for projects [4]. Ideally, principals must involve the teachers and other school residents to achieve schools' goals, where each member has different abilities. They can help principals in matters related to learning, one of the completeness of schools' facilities and infrastructure.

\section{2) Complementing Facilities and Infrastructure}

School equipment and infrastructure facilities can be obtained from various sources like students' donation and government assistance. Procurement of facilities and infrastructure is also the responsibility of the principal, this is in line with the opinion of Davis that the types of leadership skills is providing the equipment and infrastructure [3]. For example, education leaders need to learn about learning tools. To find out about teaching and learning activities, principals must use and understand what tools and facilities which are needed to support the education process. This is the responsibility for principals, because the tools can support learning activities.

\section{3) Decision making}

The principal also has responsibility in making decisions in several ways, which are directly taken by the principal and with consideration. This is in accordance with the opinion of Rohman that the principal must "lead from the center, being democratize, can perform to answer such question, and is able to rule in decision-making" [12], and Wu, Hui-Tzu's opinion "that the principal has the right and authority to make decisions" [13].

The principal makes a decision according to the need, if this decision is related to the personal rights of the principal, the decision is taken directly by the principal without doing anything complicated first, but for general decisions the principle should involve others to solve the problem together. The meeting is also consisted of deliberations with teachers, guardians or with superiors or services. As a leader, the principal must be able to solve such problems to be discussed and which should be decided (according to Muller and Turner about different leadership styles in different situations) [14]. Ideally, the decision making is the right of the principal, but the principle must also be able to adjust the decision according to the needs and the subject concerned so that it will produce the right decision.

\section{4) Establiing Good Relationships}

The principal should also have good relations with school's residents; also they are required to have good relations with the community around the school by establishing friendship, cooperative and respect manner. This is in line with the results of research conducted by Arlestig, Helena and Monika Torsen that a leader must have the skill to respect the ability of each member with different characteristics[15].

Ideally, the headmaster of the school must be able to understand and appreciate the characteristics of schools' residents and the community around the school, for example by approaching them with good cooperation so that the existence of the school is recognized by the surrounding community.

\section{B. The Role of the Principal as an Academic Supervisor}

According to the results of observation, the principal fulfills the obligation as an academic supervisor. This supervision activity is carried out on all teachers, both senior and junior teachers, in accordance with the opinion of Tesfaw and Hofman that supervision is not sufficiently available for beginner and experienced teachers [16]. This supervision is carried out with the aim to control and assess learning activities in the classroom. This is in line with the opinion of Glickman that the purpose of supervision is to improve learning instruction, so that students will be able to master basic skills, solve problems, become social builders, develop personality and being critical thinking [17]. Winston argues that most importantly, supervision has the aim of raising school standards and achieving school development [18]. Moreover Sule's opinion about supervision (internal or 
external) becomes a real instrument for examining teacher performance [19]. Usman argues that supervision is very important in the development of any education program [20], and Donkoh and Dwamena stated that it positively effects on the educational supervision on their professional development in terms of developing experiences, curriculum, teaching methods and materials, classroom management, characteristics of pupils they teach, and assessment techniques [21].

Academic supervision is indeed the responsibility of the principal. This supervision must be done so that the principal can find out the abilities and knowledge of each teacher, because teachers who have good knowledge and abilities will provide good learning to students. This is in accordance with Adewale's opinion. Teaching provides challenges, excitement, personal rewards and a chance to encourage and support others to achieve their goals [22].

\section{1) Preparation of Academic Supervision Schedule}

Before conducting academic supervision, the principal and teacher need to prepare a supervision schedule. Preparation of the academic supervision schedule is arranged in two ways, namely by agreement with the teacher and immediate supervision that is only known by the principal. The principal must be able to foster teachers to improve the quality of teaching, this is in line with Beach and Reinhartz's proposal that supervisors must be mentors and friends in relationships to support teachers and provide support in a relaxed atmosphere to provide a positive classroom learning environment [23].

The academic supervision schedule which is done with mutual agreement with the teacher adjusts the teacher's teaching schedule, so that the teacher can prepare matters related to supervision. In the other hand, the immediate supervision is done by visiting the class without telling the teacher in advance. These two methods are in line with the opinions of Soetopo and Soemanto that there are several types of class visits. "(1) Visits without prior notice, which means the principal suddenly comes to class when the teacher teaches, (2) Visits by notifying class that has been planned and given to each class to be visited [24]. This is done to find out the teacher's performance whether there are differences in supervision results that are notified in advance compared to supervision without being notified to the teacher.

Indeed, the supervision schedule should be done in two ways, by informing the teacher first and sudden one. For the first schedule, both parties can know, but for a sudden schedule only the principal knows, this is done so that the principal can find out the original readiness of the teacher in each teaching process.

\section{2) Implementation of Academic Supervision}

The implementation of academic supervision is carried out by class visits, informal meetings and visits to other schools. The principal as a supervisor has the ability to have a positive influence on supervised teachers provides guidance to teachers regarding good learning. This is in accordance with Lukum's opinion that academic supervision must be able to create professional teachers who have the ability to develop the learning process [25]. The principal as an academic supervisor has the ability to influence teachers to improve their performance. This is in line with Kelehear's opinion that supervisors with skills such as observation skills, analytical skills, data collection skills, counseling and mentoring skills have a better influence on the success of their clients [26]. And Nazer argued a significant relationship between supervisors practices among supervisors and high attitude as the foundation of professional teachers [27].

Ideally this academic supervision can be done with several techniques according to the needs and circumstances at school. Academic supervision can be performed by class visits, informal meetings and visits to other schools. The schools that visit can learn some of the superior systems owned by the schools visited. The principal as an academic supervisor must have the ability to influence the teacher in improving his performance and provide good guidance on all matters relating to learning in the classroom. Therefore the principal must have extensive knowledge about learning.

\section{3) Follow up on Academic Supervision}

Follow-up to this academic supervision is done after the report is complete and then the activities are carried out in accordance with the results of the report. Follow-up supervision is in the form training according to teachers' needs. This is in accordance with the opinion of Azhar, stating that follow-up consists of reporting and monitoring [28]. This supervision has a positive impact on the teacher that is showed every year that the results of the teacher performance assessment are increasing. Indeed, the teachers should receive special guidance according to their needs to improve their knowledge and performance.

\section{Supporting Factors for Academic Supervision}

Supporting factors for the implementation of academic supervision are the awareness that teachers have on the importance of implementing supervision. This is in line with the opinion of Ozdemir and Yirci in their research that teachers recognize education and training to train the needed skills [29]. Before learning, the teachers have prepared learning tools and other learning support tools. According to the researchers this is a mandatory task for the teacher to do, whereas if there are still shortcomings, it can be overcome by attending learning trainings.

\section{Inhibiting Factors}

The inhibiting factor in the implementation of this supervision is the busyness of the school principal with sudden service duties. It requires the school principal to increase school supervision for some time. Besides, there are still teachers who have difficulty preparing the learning tools. This is handled by involving teachers in training, because the teacher's ability can influence education system, this is in accordance with the opinion of Obadara that the level of teacher ability greatly influences the success of the education system and as a key to the development of education [30]. According to researchers, the sudden busyness of school principals can indeed be a barrier to the implementation of supervision because it can lead to supervision that is not on 
schedule. The presence of teachers who are still having difficulty preparing learning tools can also lead to poor supervision, because assessment in supervision also depends on the learning which belongs to every teacher.

\section{CONCLUSION}

The conclusions in this study are: (1) in achieving the goals, principal and teachers need to plan and divide the tasks in the meeting, (2) facilities and infrastructure equipped with funds can be obtained from various sources, (3) decisions can be taken directly by the principal and there should be consultation with the relevant parties, (4) the principal establishes good relationships with the citizens of the school and around the school, (5) the supervision schedule is drawn up in agreement with the relevant teacher and directly determined by the principal, (6) academic supervision is done 2-3 times in 1 semester with class visit technique, informal meeting and other school visit, (7) follow up of this academic supervision is in the form of teachers' participation in training, (8) factors supporting academic supervision are teachers' awareness, and (9) the inhibiting factor is that there are teachers who are still having difficulty to complete learning tools and principals who often get unannounced duty.

\section{Suggestion}

Suggestions for this research are as follows: (1) the principal always maintains communication with the teachers and the school community in team work, so that the school's goals can be achieved well and on target, (2) principals and teachers should consider the facilities and infrastructure in schools, so that learners would feel comfortable when learning, (3) as a leader, the principal should always dare to take risks in making decisions by looking at and analyzing existing problems, (4) principals continue to strengthen good relationships with all residents of schools and communities around the school, (5) schedule of supervision should be arranged in detail at every time in a new school year's plan so that teachers can perform better preparation, (6) the principal should develop techniques such as classroom observations and others, (7) the principal always provides guidance and includes teacher training to increase teachers' knowledge, and (8) the principal continues to motivate the teacher to improve his / her abilities by providing guidance and engaging the teacher in the training.

\section{References}

[1] B. M. Bass, "Bass and \& Stodgill's Handbook of Leadership: Theory, Research, and Applications, 3e éd." The Free Press, 1990.

[2] A. J. DuBrin, "Principles of leadership," 2010.

[3] K. Davis and J. W. Newstrom, "Human behavior at work: Organizational behavior," 1989.

[4] A. Pettigrew, The management of strategic change. Wiley-Blackwell, 1988.

[5] M. G. Kocher, G. Pogrebna, and M. Sutter, "Other-regarding preferences and leadership styles," 2009.

[6] G. Gibbs, C. Knapper, and S. Piccinin, "Disciplinary and contextually appropriate approaches to leadership of teaching in research-intensive academic departments in higher education," High. Educ. Q., vol. 62, no. 4, pp. 416-436, 2008.

[7] A. Luthra and R. Dahiya, "Effective Leadership is All About Communicating Effectively: Coonnecting Leadership and Communication," Int. J. Manag. Bus. Stud., vol. 5, no. 3, 2015.

[8] V. F. Peretomode, Introduction to the teaching profession in Nigeria. Total Publishers Ltd., 1992.

[9] S. Danim, "Kepemimpinan pendidikan,” Bandung Alf., 2010.

[10] M. N. Purwanto, Administrasi dan supervisi pendidikan. Remadja Karya, 1987.

[11] M. B. Miles, A. M. Huberman, and J. Saldana, Qualitative data analysis. Sage, 2013.

[12] M. Rohman and A. Sofan, "Manajemen Pendidikan," Jakarta PT Prestasi Persada, 2012.

[13] H.-T. Wu, "Educational Leadership and Supervision's Administration for Successful Schools," Int. J. Innov. Educ. Res., vol. 5, no. 10, pp. 140-152, 2017.

[14] R. Müller and J. R. Turner, "Matching the project manager's leadership style to project type," Int. J. Proj. Manag., vol. 25, no. 1, pp. 21-32, 2007.

[15] H. Ärlestig and M. Törnsen, "Classroom observations and supervisionessential dimensions of pedagogical leadership," Int. J. Educ. Manag., vol. 28, no. 7, pp. 856-868, 2014.

[16] T. A. Tesfaw and R. H. Hofman, "Relationship between instructional supervision and professional development," Int. Educ. J. Comp. Perspect., vol. 13, no. 1, pp. 82-99, 2014.

[17] C. D. Glickman, S. P. Gordon, and J. M. Ross-Gordon, Supervision and instructional leadership: A developmental approach. ERIC, 2001.

[18] B. E. Winston and K. Patterson, "An integrative definition of leadership," Int. J. Leadersh. Stud., vol. 1, no. 2, pp. 6-66, 2006.

[19] M. Sule, "The Influence of the Principal's Supervisory Demonstration Strategy on Teachers' Job Performance in Nigeria Secondary Schools," IOSR J. Humanit. Soc. Sci., vol. 11, no. 1, pp. 39-44, 2013.

[20] Y. D. Usman, "The Impact of Instructional Supervision on Academic Performance of Secondary School Students in Nasarawa State, Nigeria.," J. Educ. Pract., vol. 6, no. 10, pp. 160-167, 2015.

[21] K. Esia-Donkoh and E. Ofosu-Dwamena, "Effects of educational supervision on professional development: Perception of public basic school teachers at Winneba, Ghana," Br. J. Educ. 2, pp. 63-82, 2014.

[22] O. S. Adewale, "Desirable Transformation of Secondary School Education to Greater Heights through Effective Academic Supervision by the Vice-Principals."

[23] D. M. Beach and J. Reinhartz, "A book on supervisory leadership focusing on instruction." Boston: Allyn and Bacon, 2000.

[24] S. Hendiyat and W. Soemanto, "Kepemimpinan dan Supervisi Pendidikan," Jakarta PT. Bina Aksara, 1988.

[25] A. Lukum, "Evaluation of science learning supervision on secondary schools," Int. J. Educ., vol. 5, no. 4, pp. 61-81, 2013.

[26] Z. Kelehear, "Pass the Crayons: Leadership, Art Production, and Communities of Practice," Int. J. Educ. Policy Leadersh., vol. 5, no. 10, 2010.

[27] M. Al Nazer and G. H. A. R. Mohammad, "Supervising Practices of Education Supervisors and their Relationship with the Attitudes of High Basic Stage Teachers towards the Profession in the Capital Amman Governorate from their Point of View."

[28] L. M. Azhar, "Supervisi Klinis.” Surabaya: Usaha Nasional, 1996.

[29] T. Y. Ozdemir and R. Yirci, "A situational analysis of educational supervision in the Turkish educational system," Educ. Process Int. J., vol. 4, no. 1, p. 5, 2015.

[30] N. O. Obadara, "A prospective longitudinal study of psychological predictors of achievement," J. Sch. Psychol., vol. 34, no. 3, pp. 285-306, 2005 . 
